\title{
A Study on TBLT in College English Writing
}

\author{
Hua JIANG \\ BoHai University, JinZhou, China
}

\begin{abstract}
Writing, as the important aspect of language teaching is regarded as a complex cognitive activity and the difficult part in college English teaching. This paper analyzes the current situation of college English writing teaching, reviews the development of task-based language teaching and related background rationales, testifies the effectiveness of task-based language teaching in college English writing and proposes suggestions to future study.
\end{abstract}

KEYWORD: College English Writing; Task; Task-based language teaching (TBLT)

\section{INTRODUCTION}

Writing, as a productive skill, is an important part of language proficiency and an important means of communication. As the development of the society, it is no longer just a means of reinforcing what has already been learnt or simply an aid to learn English, but a tool for people to communicate in a real world. But learning to write in a foreign language is an uphill struggle for most non-English major college students in China. They are making complains of low motivation in a boring writing class, less chance to express their own ideas and at loss when doing some writing assignments. Most students have no clear aims to learn English writing and don't know the real purpose of English writing. Many of them think that the purpose of English writing is to reinforce what they have learned, some students even think they are writing for the teacher. Thus, day by day the wrong attitude leads them to a vicious circle. Task-based approach of language teaching is the teaching theories put forward by the foreign language teaching method researchers and the second language acquisition researchers according to the large quantity of studies and practice in the 1980s[1]. When Prabhu made an experiment of the communicative classroom in the south of India, known as Bangalore Project. Prabhu suggests various types of tasks and argues that all language items were learned by asking students to complete a certain type of task. [2] This task is considered to be the first try to achieve a class by this approach, which aroused great interest in the language-teaching field. So task-baed approach has been a new developing form of communicative language teaching in the past 25 years.

\section{EXPERIMENTAL}

\subsection{Subjects}

The subjects who participated in the study are freshmen of non-English at BoHai University. They attend their English classes 2 times a week regularly and 100 minutes of each time for 16 weeks in one semester.

\subsection{Instruments}

The instruments adopted in this experiment are pretest and post-test of writing, SPSS software and class observation.

\subsection{Procedure}

The whole freshmen took part in the English proficiency test after they entered the university one week later, of which writing was one part. Two classes of the similar proficiency level from four classes the writer taught were chosen to take part in this study. The pre-test paper was CET4 test paper, and writing part of each paper were marked by two teachers who have the experience in scoring writing part of CET4 test according to the scoring requirements of CET4, so the validity were guaranteed. The scores of writing part were taken into account in this study as the pre-test writing scores. 
The experiment started from September 15, 2013 and lasted 15 weeks till December 30, 2013. Because there was no separate writing class in our university, writing teaching was involved in the comprehensive English class. The writing teaching took one period (50 minutes) every other week.

In control class, the writer adopted traditional product approach, as the following steps[3]:

Step 1: The teacher introduced the topic and requirement of writing and offer a model composition and helped students to analyze the structure and explained some writing skills in it.

Step 2: The students imitated the model and wrote the compositions individually.

Step 3: The students revised their compositions and handed them in.

Step 4: teacher marked and commented on their compositions.

While in experimental class, the writer used taskbased approach in writing teaching. Based on Willis's framework of TBLT mentioned in previous chapter, the procedure was designed in three stages: pre-task stage, task cycle and post-task stage.
The experiment lasted for 15 weeks, after the experiment there was a post-test for experimental group and control group at the end of the term. This test for the two groups uses the writing topic of CET4 at the same time and the same place. Then there was a questionnaire for experimental group on their interest in English writing and attitude towards TBLT and three days later after post-test, there was an interview held for 12 students from experimental group in the classroom in order to get a deep understanding of the students' attitude toward TBLT[4].

\section{RESULTS AND DISCUSSION}

In order to explore whether task-based language teaching will bring forth significant improvement in college EFL learners' writing proficiency, the analysis based on quantitative data is supposed to provide readers with more direct and convincing evidence.

Table 1 Independent samples t-test results of the pre-test

\begin{tabular}{|c|c|c|c|c|c|c|}
\hline & Group & $\mathrm{N}$ & Mean & T Value & Std. Deviation & Sig. (2-tailed) \\
\hline \multirow{2}{*}{ Pre-test } & EG & 54 & 8.1296 & \multirow{2}{*}{-.025} & 1.67159 & .980 \\
\cline { 2 - 4 } & CG & 58 & 8.1379 & & 1.80106 & \\
\hline
\end{tabular}

Note: $E G=$ experimental group; $C G=$ control group; $N=$ number

As is shown clearly in Table 1 , it is a comparison of writing proficiency in pre-test between experimental group and control group. In the pre-test the mean score of the experimental group is 8.1296, a little lower than the control group which is 8.1379. $\mathrm{t}=-.025$, Sig. (2-tailed) is $.980(\mathrm{p}>.05)$ means two groups showed no significant difference in their writing performance before the experiment. We can be confident that any effects due to instruction are not related to prior knowledge or ability of any group and the proceeding statistical analysis is meaningful.

Table 2 Comparison of content, organization and language of control group in pre-test and post-test

\begin{tabular}{|c|c|c|c|c|c|c|}
\hline & Group & $\mathrm{N}$ & Mean & T value & Std. Deviation & Sig. (2-tailed) \\
\hline Content & Cpre & 58 & 2.7069 & -3.947 & .77252 & .70001 \\
& Cpost & & 3.0345 & .000 \\
\hline Organization & Cpre & 58 & 2.8621 & -1.383 & .73624 & .81650 \\
& Cpost & & 3.0000 & .172 \\
\hline Language & Cpre & 58 & 2.5517 & -.962 & .77624 & .71814 \\
& Cpost & & 2.6379 & .340 \\
\hline
\end{tabular}

Table 3 Comparison of content, organization and language of experimental group in pre-test and post-test

\begin{tabular}{|c|c|c|c|c|c|c|}
\hline & Group & $\mathrm{N}$ & Mean & $\mathrm{T}$ value & Std. Deviation & Sig. (2-tailed) \\
\hline Content & $\begin{array}{l}\text { Epre } \\
\text { Epost }\end{array}$ & 54 & $\begin{array}{l}2.8333 \\
3.6852\end{array}$ & -8.801 & $\begin{array}{l}.69364 \\
.74793\end{array}$ & .000 \\
\hline Organization & $\begin{array}{c}\text { Epre } \\
\text { Epost }\end{array}$ & 54 & $\begin{array}{l}2.7407 \\
3.4815 \\
\end{array}$ & -6.571 & $\begin{array}{r}.75698 \\
.77071 \\
\end{array}$ & .000 \\
\hline Language & $\begin{array}{l}\text { Epre } \\
\text { Epost }\end{array}$ & 54 & $\begin{array}{l}2.5370 \\
2.9074 \\
\end{array}$ & -4.169 & $\begin{array}{l}.84033 \\
.85271 \\
\end{array}$ & .000 \\
\hline
\end{tabular}


Table 4 Comparison of content, organization and language of two groups in post-test

\begin{tabular}{|c|c|c|c|c|c|c|}
\hline & Group & $\mathrm{N}$ & Mean & T value & Std. Deviation & Sig. (2-tailed) \\
\hline content & EG & 54 & 3.6852 & 4.756 & .74793 & .000 \\
& CG & 58 & 3.0345 & & .68627 & .77071 \\
\hline organization & EG & 54 & 3.4815 & 3.204 & .75028 & .002 \\
& CG & 58 & 3.0000 & & .85271 & .073 \\
\hline language & EG & 54 & 2.9074 & 1.813 & .83264 & .073 \\
& CG & 58 & 2.6379 & & & \\
\hline
\end{tabular}

From Table 2 and 3, the paired samples test of each group in pre-test and post-test, we may see that the control group only improved in "content" while experimental group made improvement in "content" "organization" and "language". The increase is much more significant for the experimental group. From Table 4, we can see that after the experiment, the two groups made significant difference in term of "content" and "organization" with the Sig. (2-tailed) is .000 and .002 $(\mathrm{p}<0.05)$ while no significant difference in the term of "language" for the Sig. (2tailed) shows $.073(\mathrm{p}>0.05)$. This may because the students of experimental group are familiar with the flexible time in the daily practice, but in the posttest, the time is limited there was not enough time for them to pay more attention on the grammar, spelling or punctuation. Another reason may be that under the TBLT model, they are highly appreciated the peer-evaluation, to some extents they depend on the correction of language errors from peerfeedback. Though in the aspect of "language" there is no significant difference statistically, it can still reveal the improvement after the experiment as a whole for experimental group.

Table 5 Independent samples t-test results of the post-test

\begin{tabular}{|c|c|c|c|c|c|c|}
\hline & Group & $\mathrm{N}$ & Mean & T Value & Std. Deviation & Sig. (2-tailed) \\
\hline \multirow{2}{*}{ Post-test } & EG & 54 & 10.0741 & \multirow{2}{*}{4.288} & 1.92159 & \\
\cline { 2 - 4 } & CG & 58 & 8.6207 & 4.66309 & .000 \\
\hline
\end{tabular}

Table 5 indicates that the post-test mean score of the experiment is also higher than that of the control class by about 1.45 points. What's more, in regard to either the former or the latter, such a difference is very significant in terms of statistics for the reason that $\mathrm{t}=4.288 \mathrm{Sig}$. (2-tailed) is $.000(\mathrm{p}<0.05)$. So it can be concluded that the experimental group outperformed the control group in the mean of the total score and such a significant increase in mean scores of writing tests can be considered as the most convincing evidence of a significant improvement of subjects' writing proficiency under task-based language teaching[5].

\section{CONCLUSION}

Firstly, the students show great interest in task-based writing. Secondly, TBLT results in significant improvement of English writing proficiency in its learners, manifested as concerning that content and organization development and language accuracy has been improved. Thirdly, the teacher is expected to play multiple roles, including analyzing learners' needs before designing tasks, adjusting groups and providing the necessary help. These roles indicate that the teacher has become less dominant in the task-based instructions. The role of the teacher, therefore, is more of a consultant than of an instructor.

\section{REFERENCES}

[1] Nunan, D. 1991. Communicative tasks and the language curriculum. TESOL Quarterly, 25(2), 279-295

[2] Crookes, G. 1986. Task classification: A cross disciplinary review. Technical Report No. 4: Center for Second Language Classroom Research. Honolulu: University of Hawaii.

[3] Nunan, D. 1989. Designing Task for the Communicative Classroom. Cambridge University Press.

[4] Ellis, R. 1994. The Study of Second Language Acquisition. Oxford: oxford University Press.

[5] Horowitz, D. 1986. What professors actually requires: academic tasks for the EFL classrooms, TESOL Quarterly, 20(1), 445-462. 